Kumawula, Vol. 2, No.3, Desember 2019, Hal 270 - 280

DOI:http://10.24198/kumawula.v1i3.24701

ISSN 2620-844X (online)

Tersedia online di http://jurnal.unpad.ac.id/kumawula/index

\title{
PENGEMBANGAN POTENSI KEWIRAUSAHAAN DI DESA CIKERUH MELALUI PROGRAM “CIKERUHPRENEUR” DAN PRODUK UNGGULAN "PA'ENGSIT"
}

\author{
Rd Ahmad Buchari' ${ }^{1}$, Ivan Darmawan ${ }^{2}$, Saifullah Zakaria ${ }^{3}$ \\ ${ }^{1}$ Departemen Administrasi Publik FISIP Unpad, ${ }^{2}$ Departemen Ilmu Pemerintahan FISIP Unpad, \\ ${ }^{3}$ Departemen Antropologi FISIP Unpad \\ 19ahmad_buchari@yahoo.com, ${ }^{1}$ ahmad.buchari@unpad.ac.id, ${ }^{2}$ ivan.idevice@gmail.com, \\ ${ }^{3}$ saifullah.zakaria@unpad.ac.id
}

\begin{abstract}
ABSTRAK
Kecamatan Jatinangor dulunya bernama Kecamatan Cikeruh. Menurut warga desa, Kecamatan Jatinangor baru diubah namanya ketika dibangunnya perguruan tinggi seperti UNPAD, ITB dan IKOPIN. Sekarang, desa Cikeruh melingkupi $11 \mathrm{RW}$ dengan berbagai potensi dan masalahnya masing-masing. Melalui pendekatan kewirausahaan, kami berusaha untuk menggali dan meningkatkan potensi-potensi yang ada di daerah-daerah tersebut, dan menyelesaikan permasalahan yang ada. Melalui "Pa'Engsit" dan "Cikeruhpreneur", kami berusaha untuk mencapai target- target tersebut.
\end{abstract}

Kata Kunci: cikeruh; desa; jatinangor; KKN; wirausaha

\section{DEVELOPMENT OF THE ENTREPRENEURSHIP POTENTIAL IN CIKERUH VILLAGE THROUGH THE "CIKERUHPRENEUR" PROGRAM AND "PA'ENGSIT" FEATURED PRODUCT}

\begin{abstract}
Jatinangor Sub-District used to be called Cikeruh. According to the village inhabitants, Jatinangor Sub-District changed its name during the time that universities like Unpad, ITB, and IKOPIN were built there. In recent times, Cikeruh village consists of $11 \mathrm{RW}$ with their own potentials and problems. Through an entrepreneurship focused approach, we try to identify and develop the potentials that reside in the area, and also find solutions to the problems they face. Through "PaEngsit" and "Cikeruhpreneur" we strive towards those targets.
\end{abstract}

Keywords: cikeruh, village; jatinangor; KKN; entrepreneur

\section{PENDAHULUAN}

Jatinangor adalah salah satu daerah pendidikan di Jawa Barat yang menjadi tempat bagi banyak kampus ternama, seperti Universitas Padjadjaran dan Institut Teknologi Bandung. Hal ini membuat kependudukan di Jatinangor didominasi oleh banyak 
mahasiswa dari dua kampus tersebut, khususnya Universitas Padjadjaran. Mahasiswa penghuni Kecamatan Jatinangor ini tersebar kedalam 12 Kelurahan/Desa, mulai dari Kelurahan/Desa Cibeusi, hingga Kelurahan/Desa Sayang.

Selama masa kolonial, Jatinangor adalah area perkebunan teh dan karet yang dikendalikan oleh perusahaan swasta Belanda, Maatschappij tot Exploitatie der BaudLanden yang didirikan pada tahun 1841, dengan luas 962 hektar pada waktu itu , membentang dari tanah - yang saat ini menjadi wilayah Institut Institut Pemerintahan Dalam Negeri (IPDN) hingga Gunung Manglayang. Perusahaan itu dimiliki oleh seorang pria Jerman, bernama Willem Abraham Baud (1816-1879) atau lebih dikenal di masyarakat sebagai Baron Baud. Untuk mengendalikan tanahnya yang luas, Baron Baud membangun sebuah menara. Menara ini dilengkapi dengan bel yang terletak di atas menara dan tangga untuk sampai ke puncak. Menara ini kemudian dikenal sebagai Menara Loji.

Untuk mempercepat transportasi produk perkebunan, pada tahun 1916 dibangun jalur kereta api yang menghubungkan Rancaekek ke Tanjungsari dalam program proyek kereta api Rancaekek-Tanjungsari-Citali sepanjang 15 km, sesuai dengan Koninklijke Besluit (Peraturan Negara) pada 4 Januari 1916 dan Lembaran Negara. Nomor 36. [9] Awalnya hanya kereta api Rancaekek-Jatinangor yang hanya 5,25 km yang akan dibangun untuk tujuan mengangkut perkebunan Jatinangor. Atas permintaan militer kereta api untuk digunakan untuk keperluan angkutan umum juga, jalur kereta api diperpanjang ke Tanjungsari dan Citali sejauh 11,5 km. [10] Namun kemudian rel kereta api ke Citali dihentikan karena kurangnya dana dan peralatan untuk menembus alam di sana sehingga rel kereta api hanya mencapai Stasiun Tanjungsari. [11] Jalur kereta api mulai dioperasikan pada 13 Februari 1921.

Kemudian, pada tahun 1918, Staat Spoorwagen Verenidge Spoorwegbedrijf, sebuah perusahaan kereta api milik Belanda membangun jembatan kereta penghubung Rancaekek-Tanjungsari yang disebut Jembatan Cikuda atau lebih dikenal sebagai Jembatan Cincin. Jembatan ini dilintasi oleh kereta yang mendukung kelancaran perkebunan karet dan transportasi umum.

Memasuki masa kemerdekaan Indonesia, tanah perkebunan karet Jatinangor dinasionalisasi, dan menjadi milik Pemerintah Daerah Sumedang (Pemda). Sayangnya, 
pemerintah daerah tidak merawat situs ini dengan baik. Pada 1980, lonceng Tower Loji dicuri. Hingga saat ini, kasus pencurian ini belum terselesaikan.

Pada tahun 1990, area perkebunan diubah menjadi area pendidikan dengan pembangunan empat institusi tersier, yaitu Institut Administrasi Domestik (IPDN), Institut Manajemen Koperasi Indonesia (Ikopin), Universitas Padjadjaran dan Universitas Winaya Mukti. Nama Jatinangor sebagai nama kecamatan baru digunakan sejak tahun 2000-an. Seiring dengan hadirnya kampus-kampus ini, Jatinangor juga mengalami perkembangan fisik dan sosial yang pesat. Seperti halnya dengan lahan pertanian lainnya di Jawa, banyak lahan pertanian di Jatinangor telah diubah menjadi rumah sewaan untuk pelajar atau pusat perbelanjaan. Institut Teknologi Bandung kemudian membangun kampusnya di wilayah ini pada 2010.

Pada 2015, Kabupaten Jatinangor menjadi salah satu daerah yang ditetapkan sebagai wilayah metropolitan Bandung Raya. [20] Penentuan Jatinangor untuk menjadi daerah metropolitan di Bandung Raya, telah dinyatakan dalam Perencanaan Tata Ruang Wilayah (RTRW) di pemerintah pusat, provinsi dan kabupaten.

Melihat kondisi demografi Kecamatan Jatinangor yang memiliki banyak potensi, pengusul beranggapan pentingnya untuk memanfaatkan kondisi yang ada untuk melakukan suatu pemberdayaan yang bermanfaat bagi penduduk Jatinangor. Salah satu sistem pemberdayaan yang cukup menjanjikan adalah melalui program pembinaan kewirausahaan.

Daerah yang menjadi fokus sistem pemberdayaan kami adalah Desa Cikeruh.Sedikit latar belakang, Kecamatan Jatinangor dulunya bernama Kecamatan Cikeruh. Menurut warga desa, Kecamatan Jatinangor namanya baru diubah ketika dibangunnya perguruanperguruan tinggi di daerah tersebut seperti Unpad, ITB dan IKOPIN. Nama Jatinangor berasal dari nama sebuah tugu yang berada di depan ITB yang merupakan buatan Belanda, Oleh karena banyaknya pro-kontra yang muncul diantara para warga, maka diadakanlah rapat antara dewan dan warga desa dan terciptalah keputusan untuk mengganti nama "Kecamatan Cikeruh" menjadi "Kecamatan Jatinangor", sedangkan nama "Cikeruh" menjadi nama salah satu Desa di Kecamatan Jatinangor yang batasannya dari mulai daerah sekitar Unpad sampai Brimob di Jalan Sayang. Di Desa Cikeruh, Kepala Desa yang memimpin pada saat ini bernama Bapak Ii Jai, dan terdapat 11 RW (Rukun Warga) di Desa Cikeruh. Berkaitan dengan kegiatan yang telah pengusul lakukan, 
berikut profil okupasi warga masing-masing RW yang berhasil kami dapatkan terkait dengan kegiatan KKN Kewirausahaan.

Ketua RW 1, Ibu Iis mengungkapkan bahwa usaha yang dilakukan oleh warganya cukup heterogen, PNS $5 \%$, Ojeg 15\%, serabutan 5\% dan pedagang sebesar 75\%. Angka presentasi menunjukkan, potensi terbesar di RW 1 Desa Cikeruh adalah, Pedagang khususnya pada bidang kuliner. Di RW 1 terdapat 3 RT yaitu RT 1, 2 dan 3. Di RT 1 pedagang lebih banyak menjual sate, lalu di RT 2 banyaknya yang menjual warung nasi sedangkan RT 3 menjual bubur ayam. Dalam bidang home made terdapat usaha bunga kertas yang dibuat berdasarkan pesanan saja, yaitu milik Ibu Aneng yang berlokasi di depan Cibiuk. Selain itu, warga RW 1 banyak pula yang memiliki usaha kos yang objeknya adalah mahasiswa atau pekerja.

Adapun masalah yang temui pada wilayah RW 1 adalah kurangnya edukasi mengenai manajemen keuangan terkait permodalan, wawasan bisnis seperti mengemas produk yang baik, legalitas dan keberlangsungan dalam jangka panjang yang dilakukan dengan strategi serta pendekatan yang mudah untuk diterima dan dimengerti warga. Karang taruna (Kersawersa) tidak aktif untuk kegiatan usaha dan Ibu PKK hanya kumpul bulanan untuk kegiatan penimbangan dan mengikuti kegiatan desa saja. Tidak adanya bantuan modal yang diberikan oleh pemerintah setempat untuk para pedagang. Ketua RWpun ingin memiliki produk kuliner khas Cikeruh untuk menjadi oleh-oleh pendatang atau turis yang datang ke Jatinangor.

Warga wilayah RW 2, melakukan usaha yang juga heterogen yaitu PNS, Ojeg, Serabutan dan Pedagang. Potensi terbesar di RW 2 Desa Cikeruh yaitu pedagang kuliner dan usaha properti. Pedagang kuliner yang berjualan di sekitar RW 2 berasal dari warga lokal dan pendatang, namun lebih didominasi oleh warga pendatang. Untuk usaha properti menjamur di daerah RW 2 yang mana harga tanahnya per $\mathrm{m} 2$ dapat mencapai Rp 15 Jt. sehingga tanah di RW 2 diibaratkan "Tanah Emas”. Karang Taruna diwilayah RW 2 cukup aktif untuk kegiatan nasional tetapi ibu-ibu PKK hanya aktif untuk melakukan program di bidang kesehatan saja. Masalah yang ditemukan adalah modal dalam pengembangan usaha belum mumpuni sehingga usaha hanya dalam lingkup itu saja, kemudian citra mahasiswa yang masuk ke desa jangan sampai tidak sama sekali meninggalkan jejak, harus adanya upaya dalam membantu warga sekitar walau kecil, karna itu akan diingat sepanjang masa oleh warga yang ada disekitar Jatinangor. 
Kamar kosan, laundry, kuliner, adalah usaha yang banyak dijalankan di RW 3. Selain usaha property terdapat beberapa warga yang memiliki pekerjaan sebagai tukang ojeg baik ojeg pangkalan atau online. Untuk pemilik kosan yang ada di RW 03 didominasi oleh warga pendatang yang berinvestasi di RW 03, sedangkan untuk warga asli RW 3 sendiri hanya beberapa orang saja yang memiliki beberapa kamar kosan. Di RW 3 tidak terdapat home industry, ungkap Pak Ujang salah satu warga. Masalah yang temui adalah warga lokal dirasa kalah bersaing dengan warga pendatang dalam hal kewirausahaan, dikarenakan kurangnya ilmu dan pengalaman dalam berwirausahaan. Warga lebih berfokus pada materi (uang) dibanding mendapatkan ilmu mengenai kewirausahaan yang bertujuan untuk memajukan usaha yang dijalani.

Di RW 4 terdapat 6 RT, masyarakatnya memiliki mata pencaharian yang cukup beragam seperti karyawan, wiraswasta, bertani dan ada pula yang berjualan burung. Selain itu terdapat pula yang berwirausaha dibidang properti, namun banyak pemilik atau investornya berasal dari luar penduduk Cikeruh. Pemilik dan penjaga kostan menerapkan system bagi hasil dari usaha bidang properti ini. RT 01, 02 dan 03 merupakan daerah yang paling banyak usaha propertinya dibandingkan RT yang lain. Sedangkan di RT 04, 05 dan 06 merupakan daerah yang masih banyak penganggurannya, menurut Pak Denny (ketua RW) pengangguran didominasi oleh warganya yang baru lulus sekolah menegah ke atas, dan mereka belum memiliki pekerjaan. Di RT 04 dan 05 juga terdapat masyarakat yang bekerja dibidang pertanian dan perkebunan. Ibu-ibu PKK di RW 4 memiliki kegiatan rutin pada tanggal 4 , kegiatan itu adalah penimbangan para balita. Namun ibuibu PKK belum memiliki kegiatan kerajinan. Selain itu di RW 4 ini belum memiliki TPA.

Menurut Pak Denny masyarakatnya kurang memiliki modal sehingga ladang mata pencaharian mereka banyak yang diambil alih oleh investor dari luar penduduk Cikeruh. Terkadang jika warganya membuka usaha mandiri, dirasa kurang laku, sehingga mereka lebih memilih untuk menjualnya kepada investor dari luar penduduk Cikeruh. Masalah utama yang dihadapi wilayah ini adalah kurangnya modal dan pengetahuan masyarakat akan pentingnya berwirausaha sehingga mereka stuck dikeadaan yang seperti itu saja. Selain itu, wargapun kurang memiliki kreatifitas sehingga tidak ada kemauan untuk berinovasi dan merubah nasib.

Pak Asep, salah satu warga RW 5 mengungkapkan potensi yang terdapat di wilayah ini meliputi, Sanggar Rangon Uyut karena para pemuda di RW 5 mempunyai minat yang 
tinggi terhadap kesenian seperti Reak. Mereka kerap menngisi acara acara hajatan warga setempat atau lainnya. Kemudian Home Industry berupa Pangsit oleh Bu Enay dan Rengginang oleh $\mathrm{Bu}$ Yani. Keduanya memproduksi dan memasarkan Pangsit dan Rengginang secara mandiri. Bu Enay memproduksi pangsit setiap hari, selain pangsit beliau juga meproduksi sistik, cireng dan cemilan lainnya. Angka pengangguran yang tinggipun dapat dimanfaatkan potensinya untuk membemberdayakan wirausaha, misal untuk berdagang atau prduksi suatu barang yang bernilai harganya.

Masalah yang dihadapi wilayah RW 5 adalah mata pencaharian warganya. RW 5 memiliki angka pengangguran yang cuku besar berada pada $30-40 \%, 0 \%$ buruh, $5 \%$ buruh tani, 20-30\% pekerja pabrik, PNS 5\% dan petani 1\%. Pemasaran home industry dan jasa berupa kesenian di RW 5 juga masih dikatakan rendah. Permodalan kurang tersedia , Karang Taruna hanya aktif saat ada event event tertentu, serta BUMDES kurang aktif. Karena berada dengan Jatos, Swalayan serta Supermaret, menjadikan wirausahawan di RW 5 tersaingi usahanya. Selain itu, masih kurang terbukanya pola piker masyarakat terkait ilmu-ilmu wirausaha juga menjadi masalah yang menghambat potensi yang ada.

Di RW 6, berdasarkan nasrasumber yaitu Ibu RW serta para pemilik kos-kosan mata pencaharian masyarakat diwilayah ini heterogen. Ada yang berprofesi sebagai pedagang, jasa, buruh serta usaha properti. Usaha rumahan yang berada di RW 6 yaitu pos giro, usaha keripik Ibu Nunung dan usaha baso Ibu Yani. Banyak juga usaha kuliner dan properti yang menjamur didaerah RW 6, seperti kos elite yang baru dibangun, Casa Mia. Hambatan yang terdapat pada wilayah ini, seperti Karang Taruna dan ibu-ibu PKK yang tidak memilki kegiatan kewirausahaan, permodalan kurang tersedia dan tidak adanya pembinaan kewirausahan agar wilayah dapat berkembang lebih baik.

Pak Maskan yang merupakan ketua RW 7, mengatakan ada beberapa potensi utama diwilayahnya. Pertama dalam bidang properti, dikarenakan wilayah RW 7 berada di lingkungan perumahan, menjadikan lingkungan RW 7 menjadi tempat properti yang cukup terkenal dikarenakan di wilayah ini banyak rumah yang dijadikan kontrakan dan kost kostan untuk mahasiswa Kuliner, sektor selanjutnya yang menjadi potensi diwilayah RW 7 ini adalah di bidang kuliner, banyak pelaku usaha dibidang kuliner seperti pedagang kaki lima sampai pemilik restaurant yang cukup terkenal. selain itu terdapat home industry yang mengolah yoghurt yang di inisiasi oleh Ibu Iin. Jasa, sektor yang 
menjadi potensi selanjutnya id wilayah ini adalah jasa, jasa yang berkembang di wilayah ini adalah laundry dan juga tempat pengisian air minum. Walau di wilayah RW 7 memiliki potensi besar, tetapi terdapat pula masalah yang dihadapi, seperti banyaknya pedagang yang meminjam uang ke lintah darat sebagai modal, banyak masyarakat yang belum mengenal potensi usaha yang ada dilingkungan RW 7, serta banyaknya sampah yang dibuang disekitaran gerbang perumahan puri indah dikarenakan tidak ada tempat pembuangan sampah sementara.

RW 8 memiliki potensi dibidang usaha Sapi yang menghasilkan susu KPS (Koperasi Penyimpanan Susu) dan mayoritas adalah pengrajin senapan angin. Senapan angin menjadi pekerjaan yang masih dikembangkan di RW 8, namun tidak banyak kios yang menjual senapan angin, penjual Cipacing. Selain itu ada pabrik roti dan selai yang baru dikembangkan dua tahun ini. Brand rotinya belum ada karena hanya sebagai supplier roti tawar. Sedangkan selainya bernama selai komalasari, pekerja di pabriknya sekitar 8 orang, uangkap Pak Yayat mantan pengrajin senapan angina dan ketua tani serta Ibu Mimin sebagai Ketua RW 8. Adapun hambatan yang terdapat pada wilayah ini seperti ibu-ibu PKK tidak aktif karena memang sulit dalam mengajak untuk ikut ke acaranya. Tanah pertanian dibeli terus sehingga habis tergarap, serta petani di RW 8 kurang bisa menerima teknologi pertanian karena sudah lansia dan memiliki pemiikiran yang konvensional.

Ibu Een, istri ketua RW 9 yaitu Pak Kamaludin, Masyarakat RW 9 mengatakan, Desa Cikeruh kebanyakan bekerja sebagai buruh, petani, dan pengrajin senapan angin. Hasil pertanian utama di RW ini adalah sayur sawi juga palawija. Terdapat juga kesenian Reog yang sering menghadiri acara-acara tertentu baik di desa maupun undangan langsung dari masyarakat. Selain hal yang telah disebutkan, terdapat juga pabrik roti dan selai di RW 9 ini. Produk roti yang dihasilkan adalah berupa roti tawar yang serin digunakan untuk membuat roti bakar. Pabrik roti di RW ini merupakan salah satu potensi yang dapat dikembangkan, namun kendalanya adalah pabrik roti ini belum mendaftarkan usahanya ke BPOM untuk mendapatkan legalitas halal dan nomor registrasi BPOM.

Menurut $\mathrm{Bu}$ RW, wilayah RW 10 memiliki masyarakat yang mayoritasnya adalah pengrajin senapan angin. Terdapat pula pabrik tahu MR milik Bapak Mamad yang berlokasi di RW 10. Proses produksi disana hingga pengemasan. Untuk pemasaran dari produk tahu melalui pembelian langsung dengan datang ke pabrik dan setor ke tempat- 
tempat penjualan tahu seperti pasar di daerah Bandung. Selanjutnya Ibu PKK yang diketuai oleh Ibu Mimin selaku Bu RW 10 dahulu cukup aktif dalam membuat kreasi. Namun semakin lama semakin jarang membuat pertemuan untuk menciptakan kreasikreasi unik seperti taplak meja dari biji kopi. Karang Taruna yang ada di RW 10 kurang aktif dalam melaksanakan kegiatan bermasyarakat. Sebab, anggota Karang Taruna memiliki kesibukan sendiri-sendiri dan seringkali sulit untuk menyamakan jadwal guna membuat kumpul rutin atau aktivitas. Namun, Karang Taruna selalu aktif mempersiapkan kegiatan peringatan 17 Agustus di RW 10. Sedangkan masalah utama yang dialami wilayah ini adalah mengenai sampah. Manajemen sampah yang ada di RW 10 kurang baik. Karena RW 10 merupakan RW yang cukup padat penduduk, maka sampah yang dihasilkan juga cukup banyak. Oleh karena itu, sampah menjadi suatu masalah yang cukup urgent bagi RW 10.

Pak H. Opan sebagai ketua RW, warga RW 11 memanfaatkan sampah organik untuk dijadikan potensi usaha dengan mengubahnya menjadi pupuk organik. Ada pula usaha rias pengantin yang didirikan oleh bhayangkari. Selain itu warga RW 11 memiliki koperasi yang menjual berbagai kebutuhan pokok. Adapun masalah yang diungkapkan oleh Pak H. Opan adalah usaha rias pengantin yang menjadi potensi wilayah ini adalah usaha milik pribadi bukan merupakan usaha yang dijalani bersama oleh warga RW 11 . Beberapa warga lebih memilih untuk membeli kebutuhan pokok ke minimarket terdekat dibanding membeli ke koperasi atau warung yang ada di kawasan RW 11 karena adanya faktor gengsi serta ibu-ibu PKK dan Karang Taruna RW 11 belum memiliki kegiatan yang berkaitan dengan kewirausahaan sehingga sector wirausaha dirasa belum maksimal.

\section{METODE}

Kami berupaya untuk memaksimalkan pemberdayaan masyarakat Desa Cikeruh melalui pendirian sebuah website jual-beli online yang bernama "Cikeruhpreneur" dan menciptakanline produk makanan ringanbernama "Pa'Engsit" untuk dijual oleh wargawarga desa Cikeruh.

Cikeruhpreneur merupakan sebuah website kewirausahaan online yang terinspirasi dari website e-commerce terdahulu seperi Bukalapak, Tokopedia, mamikos.com dan lain-lain. Wirausaha online telah menjadi salah satu lini pekerjaan yang populer sejak tahun 2011. Cikeruhpreneur berdiri diatas framework website Hydroweb, menjadi tempat dijualnya barang-barang unggulan seperti Pa'Engsit, dll., menggunakan konsep seller dan 
reseller dengan sistem reward komisi, dan berkerjasama dengan US Aid, Menristekdikti, Universitas Padjadjaran, dan Pusat Inkubator Bisnis Universitas Padjadjaran.

Produk Pa'Engsit merupakan makanan ringan yang cocok untuk semua kalangan. Varian rasa yang beragam dan gurih, juga tekstur yang renyah menjadikan Pa'Engsit cocok bagi lidah banyak orang terutama remaja. Pa'Engsit ini diproduksi oleh salah satu UMKM di Desa Cikeruh yang dikelola oleh Ibu Enay. Rasa yang ditawarkan oleh produk ini antara lain rasa pedas, original, jagung bakar, jagung manis, keju, balado, rumput laut. Tidak hanya pangsit, Pa'Engsit juga menyediakan makanan ringan lainnya seperti cireng dan cheese stick.

\section{HASIL DAN PEMBAHASAN}

Pa'Engsit dapat bekerjasama dengan beberapa mitra dan dapat bekerjasama untuk membuahkan simbiosis mutualisme, pihak Pa'Engsit mendapat keuntungan karena produknya dipasarkan atau dipromosikan, dan pihak lain mendapat keuntungan dari pangsit. Potensi pengembangan Pa'Engsit ini dapat terjalin dalam berbagai bidang baik itu pemasaran, produksi, repackaging, distribusi, maupun promosi yang dapat dilakukan oleh para partner kerja terhadap calon-calon customer seperti kalangan anak - anak dan remaja, mahasiswa, warga lokal, wisatawan domestik, dan para pecinta camilan.

HARGA POKOK PRODUKSI

\begin{tabular}{|c|c|c|c|c|c|c|}
\hline No & Biaya & \multicolumn{2}{|c|}{ Satuan } & Harga & \multicolumn{2}{|r|}{ Total } \\
\hline \multicolumn{7}{|c|}{ Biaya bahan baku langs ung (D) } \\
\hline 1 & Tepung Terigu & 1 & $\mathrm{~kg}$ & $\mathrm{Rp} 10.000$ & $\mathrm{Rp}$ & 10.000 \\
\hline 2 & Tepung Tapioka & 0.5 & $\mathrm{~kg}$ & Rp $\quad 6.000$ & $\mathrm{Rp}$ & 3.000 \\
\hline 3 & Telur & 1 & butir & $\mathrm{Rp} \quad 2.000$ & $\mathrm{Rp}$ & 2.000 \\
\hline 4 & Minyak & 1 & $\mathrm{~kg}$ & $\mathrm{Rp} 12.000$ & $\mathrm{Rp}$ & 12.000 \\
\hline 5 & Penyedap rasa & 2 & bungkus & 500 & $\mathrm{Rp}$ & 1.000 \\
\hline \multicolumn{5}{|c|}{ Total $1 \mathrm{~kg}$ pangsit ( 7 bungkus kemasan) } & $\mathrm{Rp}$ & 28.000 \\
\hline \multicolumn{5}{|c|}{ Asumsi 1 bulan menghasilkan 200 bungkus } & $\mathrm{Rp}$ & 784.000 \\
\hline \multicolumn{7}{|c|}{ Biaya tenaga kerja langs ung $(\mathrm{E})$} \\
\hline 1 & Gaji tenaga kerja & 1 & orang & Rp 150.000 & $\mathrm{Rp}$ & 150.000 \\
\hline \multicolumn{7}{|c|}{ Biaya Pendukung (F) } \\
\hline 1 & Bumbu-bumbu & 8 & rasa & $\mathrm{Rp} \quad 6.000$ & $\mathrm{Rp}$ & 48.000 \\
\hline \multicolumn{5}{|c|}{ Jumlah Unit yang Dihasilkan (H) } & \multicolumn{2}{|c|}{200 bungkus/bulan } \\
\hline \multicolumn{5}{|c|}{ (G) Biaya Produksi $=\mathbf{D}+\mathbf{E}+\mathbf{F}$} & $\mathbf{R p}$ & 982.000 \\
\hline \multicolumn{5}{|c|}{ (I) Harga Pokok Produksi = G/H } & $\mathbf{R p}$ & 4.910 \\
\hline \multicolumn{5}{|c|}{ Jumlah Keuntungan yang ingin dihasilkan $(\mathrm{J})$} & & $43 \%$ \\
\hline \multicolumn{5}{|c|}{ Harga Jual $(K)=I+(I * J)$} & $\mathbf{R p}$ & 7.000 \\
\hline \multicolumn{5}{|c|}{ Ke untungan kotor $(\mathrm{L})=\mathrm{K}-\mathrm{I}$} & $\mathbf{R p}$ & 2.090 \\
\hline \multicolumn{5}{|c|}{ Keuntungan kotor/bulan } & $\mathrm{Rp}$ & 1.399 .939 \\
\hline \multicolumn{5}{|c|}{ Keuntungan kotor/tahun } & $\mathrm{Rp}$ & 16.799 .270 \\
\hline
\end{tabular}


MODAL AWAL

\begin{tabular}{|c|c|c|c|c|c|c|}
\hline No & Biaya & & atuan & Harga & & Total \\
\hline \multicolumn{7}{|c|}{ Biaya Perlengkapan (A) } \\
\hline 1 & Standpouch & 200 & bungkus & $\mathrm{Rp} \quad 1.500$ & $\mathrm{Rp}$ & 300.000 \\
\hline 2 & Sticker Print & 200 & lembar & $\mathrm{Rp} \quad 2.000$ & $\mathrm{Rp}$ & 400.000 \\
\hline \multicolumn{7}{|c|}{ Biaya Lain-lain (B) } \\
\hline 1 & Kuota & 1 & bulan & $\mathrm{Rp} 100.000$ & $\mathrm{Rp}$ & 100.000 \\
\hline \multicolumn{5}{|c|}{ (C) Modal Awal $=A+B$} & $\mathbf{R p}$ & 800.000 \\
\hline
\end{tabular}

ASET

\begin{tabular}{|c|l|c|c|c|cr|}
\hline NO & \multicolumn{1}{|c|}{ B IAYA } & \multicolumn{2}{|c|}{ SATUAN } & HARGA & \multicolumn{2}{c|}{ TOTAL } \\
\hline 1 & Mesin Penggilas & 1 & buah & $\mathrm{Rp} 120.000$ & $\mathrm{Rp}$ & 120.000 \\
\hline 2 & Wajan & 2 & buah & $\mathrm{Rp} 50.000$ & $\mathrm{Rp}$ & 100.000 \\
\hline 3 & Sutil & 1 & buah & $\mathrm{Rp} 20.000$ & $\mathrm{Rp}$ & 20.000 \\
\hline 4 & Talanan & 1 & buah & $\mathrm{Rp} 15.000$ & $\mathrm{Rp}$ & 15.000 \\
\hline 5 & Pisau & 1 & buah & $\mathrm{Rp} 10.000$ & $\mathrm{Rp}$ & 10.000 \\
\hline \multicolumn{9}{|c|}{ TOTAL } & Rp & $\mathbf{2 6 5 . 0 0 0}$ \\
\hline
\end{tabular}

- Kerjasama dengan Mahasiswa bisa terjalin karena kerap kali mahaiswa memiliki sebuah acara atau pun project, salah satu cara untuk mendanai usahanya adalah dengan berjualan dan Pa'Engsit dapat dijadikan pilihan dalam ber-danus (dana usaha).

- Kerjasama dengan Masyarakat setempat untuk dijadikan produk dagang (sebagai reseller). Pa'Engsit secara tidak langsung memberikan mata pencaharian bagi warga pengangguran dan memberikan penghasilan tambahan.

- BUMDES dapat dijadikan wadah perluasan dan pengembangan produksi Pa'Engsit .

- Koperasi Mahasiswa dan Foodcourt dapat menjadikan ladang promosi Pa'Engsit di kalangan generasi millenial.

- Toko oleh-oleh dan tempat wisata serta tempat hiburan dapat mempromosikan Pa'Engsit sebagai cemilan khas Cikeruh Jatinangor kepada masyaakat luar Jatinangor.

- Pusat Perbelanjaan, dan Pasar memiliki pengaruh dalam distribusi Pa'Engsit di masyarakat secara luas dan berbagai kalangan dapat memperolehnya.

- Pa'Engsit dapat melebarkan sayap secara luas dengan menjalin kerjasama dengan Pabrik Produksi Snack dan Pengusaha Start Up, inovasi dan terobosan (repackaging) maupun modal dapat diperoleh dari kerjasama ini. 
- Platform media social dan web Cikeruhpreneur dapat mempromosikan Pa'Engsit secara digital dan tentunya luas. Kalangan muda-mudi dan netizen dapat mengetahui eksistensi produk khas Cikeruh ini, proses jual-beli pun menjadi semakin mudah dan tak mengenal jarak.

\section{SIMPULAN}

Kami berupaya untuk memaksimalkan pemberdayaan masyarakat Desa Cikeruh melalui pendirian sebuah website jual-beli online yang bernama "Cikeruhpreneur" dan menciptakan line produk makanan ringan bernama "Pa'Engsit" untuk dijual oleh wargawarga desa Cikeruh. Cikeruhpreneur merupakan sebuah website kewirausahaan online yang terinspirasi dari website e-commerce terdahulu seperi Bukalapak, Tokopedia, mamikos.com dan lain-lain.Produk Pa'Engsit merupakan produk makanan ringan yang cocok untuk semua kalangan. Varian rasa yang beragam dan gurih, juga tekstur yang renyah menjadikan Pa'Engsit cocok bagi lidah banyak orang terutama remaja.Website wirausaha "Cikeruhpreneur" dan produk makanan ringan "Pa"Engsit" cukup dapat meningkatkan perekonomian warga Cikeruh dan memberikan pemahaman baru kepada warga mengenai dunia wirausaha dan teknologi yang menunjangnya.

\section{DAFTAR PUSTAKA}

Abdullah, Azis (12 Juni 2017). "Sejarah Jalur Kereta Api di Jatinangor, Dibangun Untuk Kebutuhan Militer". Kabar Priangan. Diakses tanggal 03 September 2019.

"Sejarah Jatinangor". Himpunan Mahasiswa Sastra Prancis Fakultas Ilmu Budaya Universitas Padjadjaran. 23 September 2014. Diakses tanggal 07 September 2019. 